\title{
COBALT DEFICIENCY IN THE KAIWERA DISTRICT, EASTERN SOUTHLAND
}

\author{
C.G. Sherrell ${ }^{1}$, P.D. Mclntosh ${ }^{*}$ and P. Brunsden ${ }^{3}$ \\ 'MAFTech, Ruakura Agricultural Centre, Hamilton \\ ${ }^{2}$ Division of Land and Soil Sciences, DSIR, Dunedin \\ ${ }^{3}$ MAFQual, Gore
}

Abstract

Soils and pastures were sampled at 96 sites in the Kaiwera district, a" area having 12 soil types typical of eastern Southland and South Otago. Analyses indicated that W-thrift" in lambs could be due to low cobalt (Co) intake. Upland (>300 m a.s.1.) topsoils had lower EDTA. extractable Co than lowland topsoils and analysis of soil profile samples indicated that Co had been leached from upper horizons of upland soils. Upland pastures contained much less Co than lowland pastures and Co concentration was much lower in February than in October. Sheep grazing on upland pasture had very low vitamin $B_{12}$ status from October to June and this coincided with low pasture Co concentration Sheep grazing on lowland pasture had adequate vitamin $B_{12}$, although pasture Co concentration fell to below $0.06 \mathrm{mg} / \mathrm{kg}$ for a short period in summer. We conclude that sheep grazed on upland pastures for long periods need supplementary Co or vitamin $\boldsymbol{B}_{12}$ or need to be rotationally grazed on lowland pasture to build up adequate reserves of vitamin $B_{12}$.

Keywords: ill-thritt, sheep, vitamin $\mathrm{B}_{12}$, pasture cobalt, seasonal variation

\section{INTRODUCTION}

Traditionally, stock in eastern Southland and South Otago have suffered from an "ill-thrift" problem. Lambs fail to gain weight and fatten despite adequate available pasture. A mineral deficiency has been suspected and some improvement in health of sheep has been noted after cobalt (Co) dosing or vitamin $\mathbf{B}_{12}$ injection, but there has been no clear explanation of why the problem occurs intermittently and not on all farms.

In this paper we report an investigation of soils and pastures of a typical area of the eastern Southland-South Otago region and describe a major difference in available Co between upland and lowland soils and in Co concentration between upland and lowland pastures. We show how this difference affects the vitamin $\mathbf{B}_{12}$ status of grazing sheep.

\section{METHODS}

\section{Soil and pasture survey}

Soil and pasture samples were collected in October 1984 from 96 sites within the area shown in Fig. 1. There were 8 sites on each of 12 soil types which are of agricultural importance in the district. Four of the soils classified as upland yellowbrown earths occur above $300 \mathrm{~m}$ altitude (average of sampled sites was $41 \mathrm{Om}$ ). The other 8 soils, classified as lowland yellow-brown earths and a recent soil, occur below $300 \mathrm{~m}$ altitude (average of sampled sites was $200 \mathrm{~m}$ ). Pastures were resampled at the same sites in February 1985.

Topsoils $(\mathrm{O}-\mathrm{I} 5 \mathrm{~cm}$ ) were analysed by MAF Quick Tests (Cornforth 1982a) and EDT\&extractable Co was determined by the method of Forbes (1976). Pasture 
samples were analysed for the complete range of major and minor nutrient elements (Cornforth 1982b) and Co (Poole 1980).

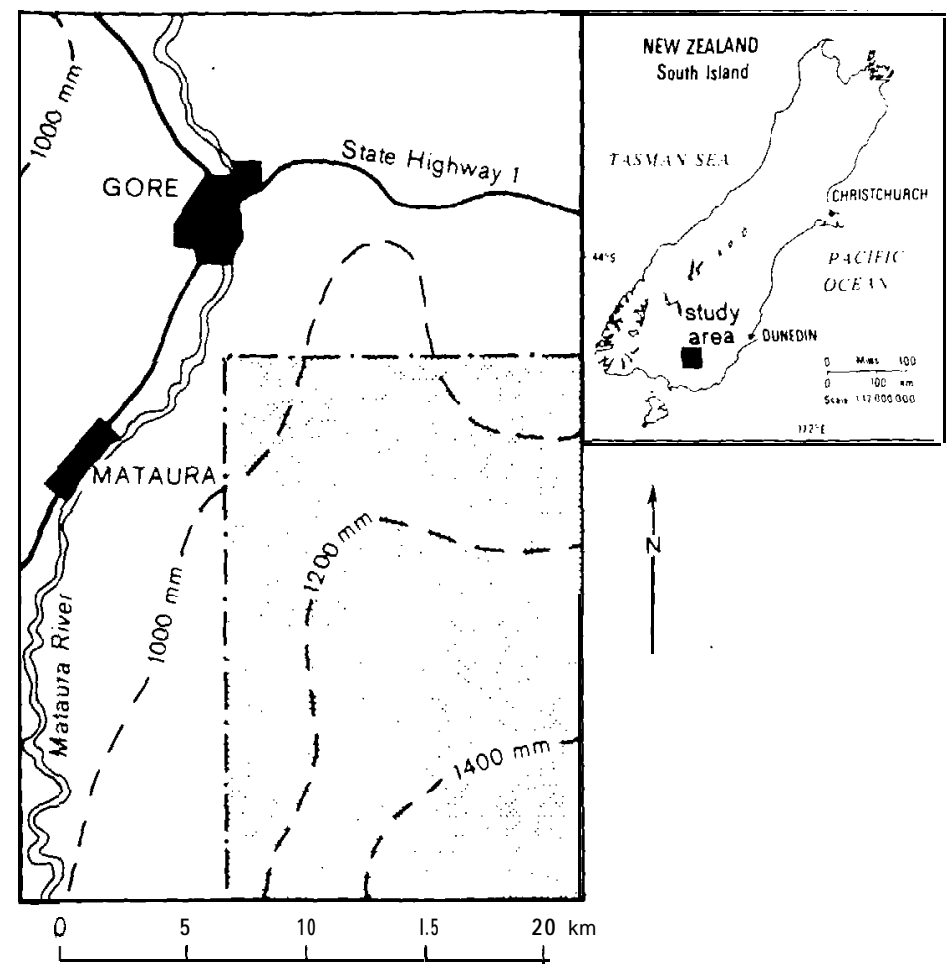

Figure 1: Location of the study area

\section{Animal grazing trials}

Two trials began in August 1985 when 12 pregnant Romney ewes were set stocked on enclosed areas at an upland (375 mm a.s.l.) and a lowland site (195 $\mathrm{m}$ a.s.l.). Lambs were born in September 1985 and were kept on the sites till September 1986. Ewes were retained on the upland site but removed from the lowland site after weaning (January).

Blood samples were taken monthly by jugular puncture and collection in evacuated tubes, Liver samples were taken from lowland ewes when they were slaughtered in January 1986, from 3 lowland lambs slaughtered in March 1986, from 2 ewes and 2 lambs on the upland site slaughtered in February 1986, and from all animals remaining in the trial in September 1986. Serum and liver vitamin $\mathbf{B}_{12}$ were determined by a radioassay method (Millar et al. 1984).

Duplicate pasture samples were collected from the animal trial sites at the same time as blood samples were obtained. In addition, pasture samples were collected from neighbouring sites on different soils (pasture monitoring sites). These were analysed to determine if the trial sites were typical upland and lowland pastures with regard to Co concentration. 


\section{RESULTS}

\section{Soil and pasture survey}

Soil Quick Test values were similar for all soils with satisfactory $\mathrm{pH}$ and medium fertility for pasture growth. Extractable soil Co was closely related to altitude. The upland soils had only about one-third of the available Co of lowland soils (Fig. 2). The difference between upland and lowland soils is attributed to leaching of Co from the upper horizons of the more acid upland soils (Mclntosh et al. 1986).
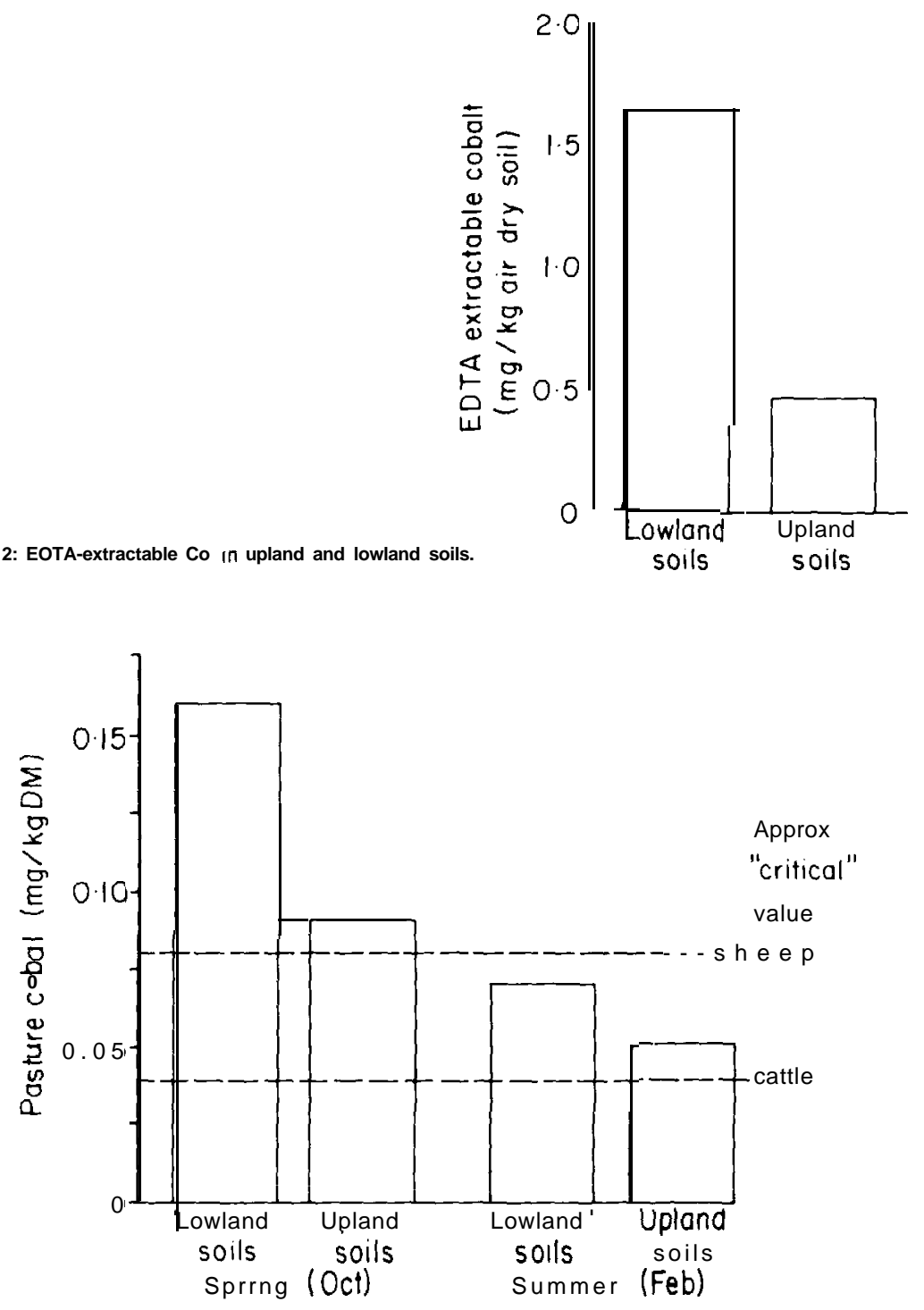

Figure 3: Pasture Co concentration in spring and summer. 
Pasture Co concentration showed the same pattern as extractable Co in soils. In October, upland pastures had only half the Co concentration of lowland pastures (Fig. 3) and some of the upland pastures were marginal or below the Co requirement for sheep (0.08 mg/kg, Agricultural Research Council 1980). In February, Co values in all samples were much lower than in October and $91 \%$ of upland pastures and $61 \%$ of lowland pastures were below $0.06 \mathrm{mg} / \mathrm{kg}$.

Other trace elements and major elements were similar in all pasture samples and were adequate for optimum pasture growth and animal requirements (Sherrell \& McIntosh 1987).

\section{Grazing trial}

Pasture cobalt concentration Pasture Co concentration at the upland animal trial site was adequate for sheep when the trial began but fell quickly to below 0.08 $\mathrm{mg} / \mathrm{kg}$ and remained at approximately $0.05 \mathrm{mg} / \mathrm{kg}$ from October to April (Fig. 4a). Values increased slightly in May and June and were adequate from July to September. Similar changes occurred in pasture $\mathrm{Co}_{0}$ concentration at the upland monitoring site (Fig. 4b).

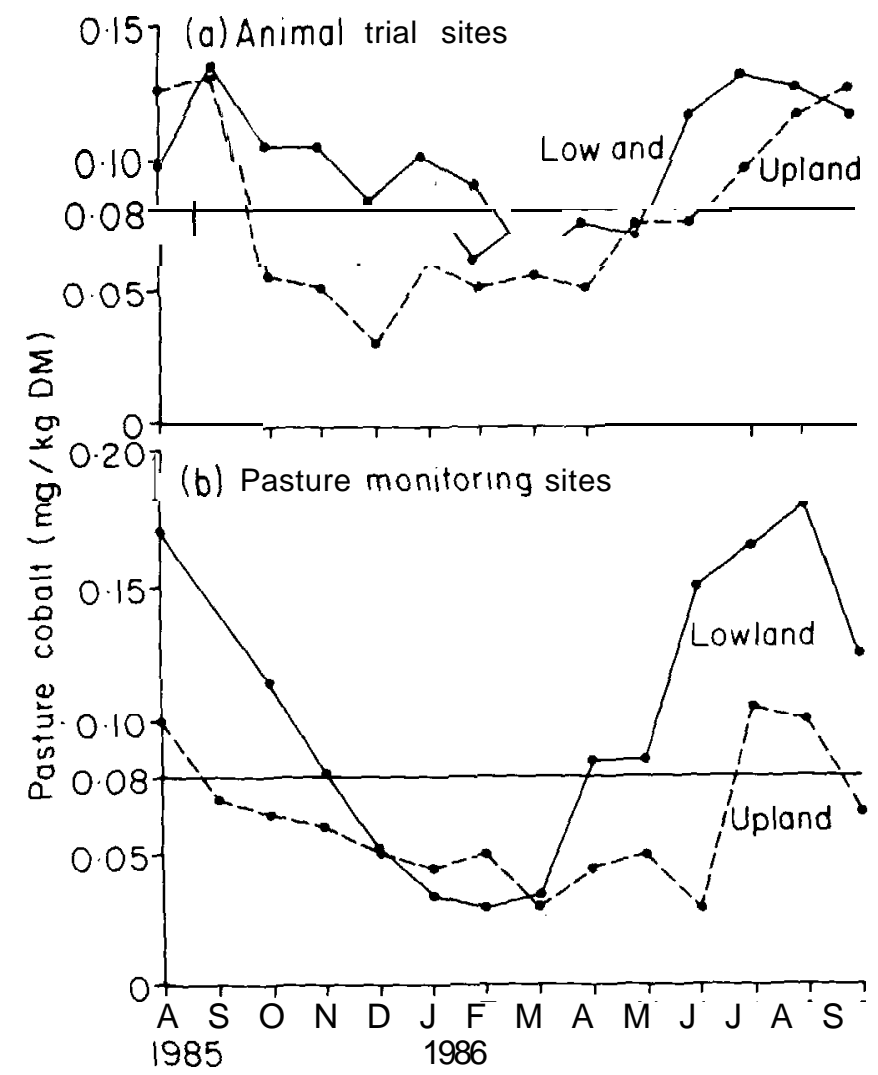

Figure 4: Pasture Co concentration in upland and lowland Pastures (a) animal trial site, (b) Pasture monitoring sites. 
Pasture Co concentration at the lowland animal trial site also decreased from adequate values in spring and early summer but did not drop below $0.08 \mathrm{mg} / \mathrm{kg}$ until March (Fig. 4a). Values remained slightly below $0.08 \mathrm{mg} / \mathrm{kg}$ till May and then increased to $0.11 \cdot 0.13 \mathrm{mg} / \mathrm{kg}$ for the remainder of the trial. Pasture on the lowland monitoring site was below $0.08 \mathrm{mg} / \mathrm{kg}$ from December to March (Fig. 4b).

Vitamin $B_{12}$ in sheep Ewes on upland pasture had satifactory serum vitamin $B_{12}$ status at the start of the trial (Fig. 5) but by October values had decreased to just above the marginal range (370 p mol/litre, Clark8 Millar 1983). Serum vitamin $\mathbf{B}_{12}$ of ewes and lambs remained marginal or in the deficient range from November to July and increased again in August and September to adequate values.

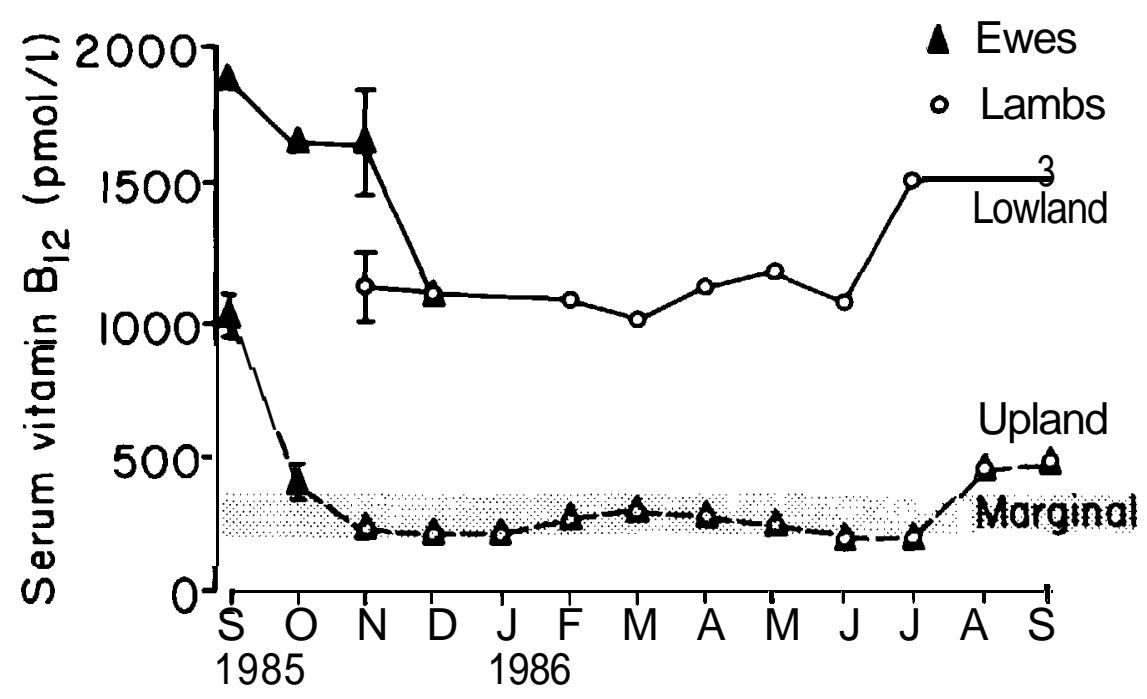

Figure 5: Serum vitamin $\mathrm{B}_{12}$ concentration of sheep grazing upland and lowland pasture.

Serum vitamin $B_{12}$ in lowland sheep showed a similar seasonal pattern to that in upland sheep but values were much higher and well into the adequate range throughout the trial (Fig. 5).

The low vitamin $B_{12}$ status of upland sheep was confirmed by liver analysis (Table 1). Upland sheep were deficient $k 110 \mathrm{n} \mathrm{mol} / \mathrm{kg}$ in February) and although values had increased by September, they were still not adequate. Lowland sheep had adequate liver vitamin $\mathbf{B}_{12}(>220 \mathrm{n} \mathrm{mol} / \mathrm{kg}$, Clark \& Millar 1983) throughout the trial.

Table $1_{\text {: Vitamin }} B_{12}$ concentration in liver of upland and lowland sheep ( $\mathrm{n} \mathrm{mol} / \mathrm{kg}$ fresh tissue)

\begin{tabular}{lcccc}
\hline & Jan & Feb & Mar & Sept 1966 \\
\hline $\begin{array}{l}\text { Upland } \\
\text { Lowland }\end{array}$ & $313(58)$ & $80(5.6)^{1}$ & & $169(14)$ \\
\hline & & & $250(32)$ & $501(65)$ \\
\hline
\end{tabular}

${ }^{1}$ SEM 


\section{DISCUSSION}

The results of the soil and pasture survey strongly suggest that lamb ill-thrift in the district is related to an inadequate Co intake, which in turn is related to soil type.

In the grazing trials, the patterns of changes in serum vitamin $\mathbf{B}_{12}$ closely followed pasture Co concentration. The patterns were identical on the upland site and they were very similar on the lowland site except that serum vitamin $\mathbf{B}_{12}$ did not decrease in the period March-May when pasture Co fell to below $0.08 \mathrm{mg} / \mathrm{kg}$. The lowland sheep had adequate reserves of liver vitamin $B_{12}$ and these were probably utilised to maintain serum vitamin $\mathbf{B}_{12}$ during the short period of low Co intake (Marston 1970). The upland sheep had inadequate liver reserves and serum vitamin $B_{12}$ fell rapidly when pasture became low in Co.

Vitamin $B_{12}$ in serum and liver can both be used to diagnose Co deficiency in sheep. Millar et al. (1987) reported that a worthwhile response to Co treatment would occur if serum vitamin $B_{12}$ was less than $336 p$ mol/litre or liver vitamin $B_{12}$ was less than $282 \mathrm{n} \mathrm{mol} / \mathrm{kg}$. In the current trial upland sheep had far lower values than these and were clearly Co deficient.

\section{Applicability of results}

Soils formed from similar parent material to those in this study cover about 310,000 ha in eastern Southland and South Otago (N.Z. Soil Bureau 1968), and about 65,000 ha in the Hokonui Hills. The distribution of Co deficiency in these districts is likely to follow the deficiency pattern found here, i.e. deficiency will be most severe on pastures on strongly leached soils, particularly those above $300 \mathrm{~m}$ altitude and the degree of deficiency on both upland and lowland pastures will depend on soil type.

\section{CONCLUSIONS}

(1) The Co intake by sheep on upland pastures of the Kaiwera district is inadequate to replenish liver reserves of vitamin $\mathbf{B}_{12}$. Lambs grazed for long periods on upland pastures should be supplemented with Co or vitamin $\mathbf{B}_{12}$ to ensure satisfactory liveweight gain. Alternatively, lambs could be grazed on lowland pastures for a period immediately after weaning to build up vitamin $\mathbf{B}_{12}$ reserves.

(2) The sporadic nature of Co deficiency in the district is related to the seasonal variation in pasture $\mathrm{Co}$ and the differences between upland and lowland pastures. Annual variation in Co availability may also be important. The occurrence of Co deficiency will depend on the soil type on which sheep are grazing and the length of time they graze pastures of inadequate Co content.

(3) The soil pattern of much of eastern Southland/South Otago and the Hokonui Hills is similar to that of the Kaiwera district so these results may have implication for an area totalling 375,000 ha. Co deficiency is likely to occur mostly on strongly leached soils, particularly those above $300 \mathrm{~m}$ altitude.

\section{Acknowledgements}

We are grateful to B 8 T Story and G. Sharp for their willing co-operation in the grazing trials; J. Gill and staff of Invermay Animal Health Laboratory for vitamin $\mathbf{B}_{12}$ determinations; Plant and Analytical Chemistry Group. Ruakura for soil quick tests and plant analyses. 


\section{REFERENCES}

Agricultural Research Council. 1980. The nutrient requirements of ruminant livestock Farnham Royal: Commonwealth Agricultural Bureaux.

Clark, R.G.; Millar, K.R. 1983. Cobalt. pp 27-37, In Grace, N.D. (Ed) The mineral requirements of grazıng ruminants N.Z. Society of Animal Production occasional publication No. 9

Cornforth, I.S. 1982a. Soil analysis interpretation. AgLink 556. Wellington: Ministry of Agriculture and Fisheries. Cornforth, IS. 1982b. Plant analysis methods and interpretation. AgLink 557. Wellington: Ministry of Agriculture and Fisheries.

Forbes, E.A. 1976. Cobalt, copper and zinc in yellow-brown pumice soils under grazed permanent pastures. N.Z journal of agricultural research 19: 153-64.

Marston, H.R. 1970. the requirement of sheep for cobalt or for vitamin $B_{12}$. British journal of nutrition 2: 61533.

McIntosh. P.D., Sherrell, C.G., Prema PG. 1986. Distribution of cobalt, copper and zinc in upland and lowland soils of the Kaiwera District Eastern Southland, New Zealand. N Z. Soil Bureau scientific report 78

Millar, K i?; Albyt, A.T; Bond, G.C 1984. Measurement of vitamin $B_{12}$ in the livers and sera of sheep and cattle and an investigation of factors influencing serum vitamin $B_{12}$ levels in sheep. N.Z. veterinary journal 32: 6570.

Miller, K.R.; Wright, D F.. Clark. R G 1987. Relationship between liveweight response and diagnostic parameters in young cobalt-deficient sheep. Proceedmgs of the 4th AAAP Animal Science Congress p. 431.

New Zealand Soil Bureau, 1968. Soils of South Island, New Zealand N.Z Soil Bureau Bulletin 27.

Poole, P R. 1980 Graphite furnace atomic absorption spectroscopic determination of cobalt and copper In herbage. Proceedmgs of New Zealand Institute of Chemistry Conference, August 1980, Palmerston North Sherrell. CG. Mclntosh PD. 1987 Nutrient status of soils and pastures in the Kaiwera district eastern Southland. New Zealand. N.Z journal of agriculturat research 30: 261-68. 